\title{
Factor Influencing Consumer's Purchase Intention on E-Commerce in Indonesia During Pandemic Covid-19 Based on Gender Moderation
}

\author{
Riski Arifin ${ }^{1 *}$, Andriansyah ${ }^{1}$, Rizki Agam Syahputra ${ }^{1}$, Awal Aflizal Zubir ${ }^{1}$ \\ ${ }^{1}$ Industrial Engineering Department, Universitas Syiah Kuala, Jl. Tgk Abdur Rauf No. 7, Banda Aceh, Indonesia \\ ${ }^{*}$ Corresponding author. Email: riskiarifin@unsyiah.ac.id
}

\begin{abstract}
The development of a new technology shifts conventional shopping behaviours from offline shopping to online shopping. The rise of e-commerce market and effect of the COVID-19 pandemic accelerate an expansion of e-commerce integration, this condition provided customers with access to variety of product in much more convenience way. This research aims to discover factors influencing costumer behaviour on purchase intention based on exogenous variables such as trust, perceived ease of use, perceived information seeking, cost-saving and moderated by the influence of gender. This research use partial least square analysis with 169 responders involved that are spread into 79 men and 90 women. By using smart-pls software, this paper discovers that $r$-square from male variable shown the value of 0,556 (indicates that there are $44,4 \%$ unknown variable) and 0.459 for the female variable (indicates that there are $54,1 \%$ unknown variable). Thus, based on the analysis, additional variables are needed to fully recognize another factor that influences purchase intention.
\end{abstract}

\section{Keywords: Moderation, E-Commerce, Survey and Mapping, smart-pls}

\section{INTRODUCTION}

The development of and internet is one of the main factors that contributes to the emergence of new technology, additionally the integration between internet of things and everyday items due to the development of industry 4.0 create positive reinforcement on human activities. The Minister of Industry of Indonesia claims that the implementation of Industry 4.0 technology to industrial sector will be a valuable contribution to the growth Gross domestic product (GDP) with estimated value of USD 120 billion to USD 150 billion in 2025 [1]. For instance, the implementation of industry 4.0 can be integrated in the commercial and shopping center, this integration will likely shift the consumer behavior from offline shopping to internet shopping or mostly know as ecommerce.

E-commerce is a process of acquiring, selling, transferring, or exchanging products, services or even information via internet network [2]. E-commerce is divided into several types, namely business-to-consumer ecommerce, business-to-business e-commerce, consumerto-consumer e-commerce, social e-commerce, mobile e- commerce, local e-commerce [3]. Shoppe, Lazada, Tokopedia, Bukalapak and Blibli.com are few examples of the most downloaded e-commerce applications that are available in Indonesia [4].it is estimated that the value of the e-commerce market in Indonesia will likely to grow between USD 55 to $\$ 65$ billion by 2022 [5].

In the covid-19 era, Indonesia's information and communication sector grew by $10.88 \%$ in second quarter of 2020, this indicates that most of financial economic instruments such as finance technology, e-commerce, dirigisme wellness service, on demand service and internets of things will likely depends on digital economic system. This sector is predicted to grow by $400 \%$ during 2020 [6].

In another words, the emergence of e-commerce in Indonesia will alter consumer behavior on shopping cultures from offline to online shopping. The availability and variety of items in online shopping compared to the offline shopping are of the main selling point that contributes to the purchase behavior.

Many researches have been conducted to analyze the purchase intention on the newly shifting purchase behavior of a consumer, research conducted inSpain founds 
that variable of trust, perceived value, fashion innovativeness have a positive influence on purchase intention, this research was conducted to 433 respondent by developing a model of trust, perceived value, electronic innovativeness and, fashion innovativeness as exogenous variables for purchase intention [7]. Additionally, research conducted to 307 respondents in Jakarta found that discount on product brand and brand image are the main factor that highly influence the purchase intention of a consumers. [8]. Another study investigated the correlation between time pressure and product involvement in to perceived value and purchase intention. 570 respondents were contributed to this research and the result found that perceived value is positively related to purchase intention. While the time pressure variable as a moderator has a negative impact on purchase value and purchase intention [9].

Based on this account, this research aims to conduct a systematic analysis to measure the correlation between purchase intention and exogenous variable, such as trust, cost saving, perceived information seeking and perceived ease of use in e-commerce transaction during the covid19 pandemic situation in Indonesia.

The Technology Acceptance Model was introduced by Davis in 1986, which is a form of acceptance of the information technology system used. The aim is to help provide a basic framework for tracing the influence of external factors on trust and help explain the acceptance of a new technological system in society [10], the Technology Acceptance Model consists of the beliefs which consist of perceived usefulness and perceived ease of use and the next side consists of attitude-behavior intention to use and usage behavior [11]. The basic model for acceptance of the Technology Acceptance Model is as follows:

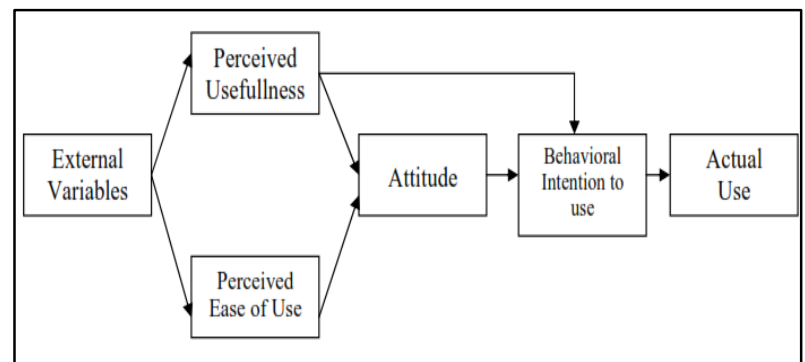

Figure 1. Technology Acceptance Model.

1. Perceived Usefulness: Defined by the extent to which a person believes that using this technology will improve his job performance, with the measurement indicators are to make work easier, accelerate work, increase productivity, effectiveness, develop job performance and be useful [10].
2. Perceived Ease of Use: It defines the extent to which a person believes that using technology will be free of effort with its measurement indicators that are easy to learn, controllable, clear and understandable, flexible, easy to use, easy to become proficient in [10].

3. Attitude toward behavior: It is defined as a person's positive and negative thoughts or feelings in performing a certain behavior [10].

4. Behavior Intention: Defined as a person's desire to carry out a certain behavior, someone will do a behavior if they have the desire or intention to do so [10].

5. Actual System use: It is an action taken by someone who uses an information technology system, where the behavior of actual use is based on the frequency and duration of information technology use [10].

One factor of TAM is used in this study, namely perceived ease of use which explains the ease of use on the buying experience in an e-commerce shop. In addition, there are several exogenous variables used, including the following:

Based on the TAM model perceived of usefulness shown positive effect on the purchase intention on e-commerce market [12]. Perceived of usefulness are more importance that perceived values. Perceived value is individual perception on the economic value of the product, while emotional value covers the social dimension of a costumer [13], [14]. Costumer will likely feel satisfied when buying a product or service in a cheaper price from offline or online shop. Thus, the hypothesis form is as follow:

H1: Variable cost saving between men and women influences purhase intention. Trust is perceived as a person's level of trust in his expectations based on the previous interactions. The importance of trust increases because of the high level of uncertainty and risk that occurs in online transactions [16]. Lack of trust is the main reason why consumers do not want to be involved in e-commerce [17].

$\mathrm{H} 2$ : Variable trust between men and women influences purchase intention Perceived information seeking is an accessible information that gain be gained from the product. New information that can be gained from a product facilitates the decision-making process and increases buyer intention [18], [19]. Information search can increase individual knowledge about products and online shops as well as skills in using platform features [20].

H3: Variable perceived information seeking between men and women influences purchase intention. Perceived ease of use has a strong relationship with 
self-efficacy, self-determination, and competence [21]. In general someone who has a high level of self-efficacy will likely makes a more accurate decision. If consumers have made transactions through e-commerce, the perception that will arise is related to satisfaction from the experience in using e-commerce. That is why someone who has an online shopping experience has a stronger will to buy through e-commerce [22], [23].

H4: Varible perceived ease of use between men and women influences purchase intention. From the overall hypotheses that has been built, gender is perceived as variable to observe the effect of exogenous variables on purchase intention. Gender moderating variables can influence user behavior in using technology [24]. Thus, in this study the effect of gender on purchase intention in using e-commerce shopping during the covid-19 pandemic is also observe.

Partial Least Square is a powerful analytical method to develop a theory in exploratory research that aims to explain the variance of the dependent variable with the existing dataset, besides that it is covariance to confirm or reject the theory to test that the proposed theory can estimate the covariance matrix for a specific dataset. The advantage of using Partial Least Square emphasizes high accuracy predictions [25], PLS does not require data to have the same distribution so that it is distributional [26], [27]. Then the data used can be a small sample size [28], with a causal model or a complex causality model that focuses on maximizing the observed constructs and not on the fit model [27]. As a technique for making predictions, Partial Least Square assumes that all measures of variance are useful variances to explain so that the latent variable estimation approach is considered as a linear combination of indicators and avoids the problem of factor indeterminacy [29].

\section{METHODS}

This study used 169 participants where the number of male participants was 79 and female participants were 90. All participants were at least 18 years old. Participants can fill out a questionnaire on the condition that they have at least purchased goods using e-commerce at least once. The participants will fill out a questionnaire related to purchase intention as an endogenous variable. There are 4 exogenous variables, namely perceived ease of use, trust, cost-saving, and information-seeking variables. This study uses a gender moderator variable to see the purchase intention of each gender. The hypotheses built are as follows:

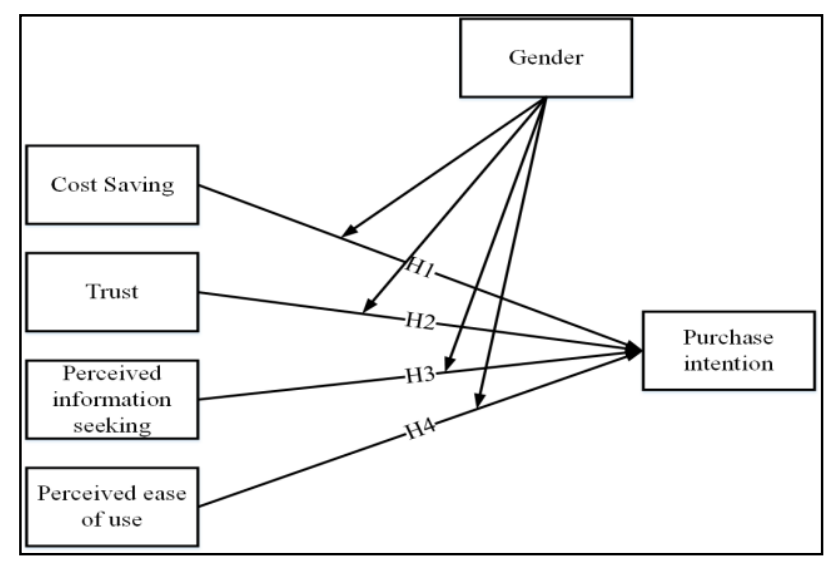

Figure 2. Hhypothesis Purchase Intention.

From the model above, there are several hypotheses built from exogenous variables to endogenous variables, while the hypotheses are as follows:

$\mathrm{H} 1$ : Variable cost saving between men and women influences purhase intention

$\mathrm{H} 2$ : Variable trust between men and women influences purchase intention

H3: Variable perceived information seeking between men and women influences purchase intention

H4: Varible perceived ease of use between men and women influences purchase intention.

\section{RESULTS AND DISCUSSION}

After all the data is obtained, the processing and analysis process is carried out using the smart-pls software. The data processing process is as follows:

\subsection{Convergent Validity}

Convergent validity is used to assess the indicator level of a latent variable or also known as indicator reliability. The reliability value is sufficient if the justification of an indicator to the latent variable is at least 0.7 [17]. In another study the outer loading value between $0.5-0.6$ is considered sufficient to qualify for convergent validity [20]. The table below shows the convergent validity of each indicator that affects the latent variable.

Based on the convergent validity table above, it shows the variable purchase intention, perceived in-formation seeking, perceived ease of use, trust, cost saving variable has a value of $>0.5$ which can be stated that each variable has valid convergent validity. 
Table 1. Convergent Validity

\begin{tabular}{|l|c|c|c|c|c|}
\hline \multirow{4}{*}{ Variable } & Indicator & Men & Verification & Women & Verification \\
\hline \multirow{4}{*}{ Perceived Ease of Use } & PEU1 & 0.768 & Valid & 0.627 & Valid \\
\cline { 2 - 6 } & PEU2 & 0.813 & Valid & 0.849 & Valid \\
\cline { 2 - 6 } & PEU3 & 0.893 & Valid & 0.771 & Valid \\
\hline \multirow{4}{*}{ Trust } & T1 & 0.822 & Valid & 0.766 & Valid \\
\cline { 2 - 6 } & T2 & 0.922 & Valid & 0.883 & Valid \\
\cline { 2 - 6 } & T3 & 0.821 & Valid & 0.845 & Valid \\
\cline { 2 - 6 } & CS1 & 0.798 & Valid & 0.765 & Valid \\
\cline { 2 - 6 } & CS2 & 0.832 & Valid & 0.637 & Valid \\
\cline { 2 - 6 } & CS3 & 0.710 & Valid & 0.837 & Valid \\
\hline \multirow{3}{*}{$\begin{array}{l}\text { Perceived Information } \\
\text { Seeking }\end{array}$} & CS4 & 0.829 & Valid & 0.788 & Valid \\
\cline { 2 - 6 } & IS2 & 0.706 & Valid & 0.502 & Valid \\
\cline { 2 - 6 } & IS3 & 0.803 & Valid & 0.703 & Valid \\
\hline \multirow{3}{*}{ Purchase Intention } & PI1 & 0.852 & Valid & 0.908 & Valid \\
\cline { 2 - 6 } & PI2 & 0.877 & Valid & 0.871 & Valid \\
\cline { 2 - 6 } & PI3 & 0.928 & Valid & 0.910 & Valid \\
\hline
\end{tabular}

\subsection{Discriminant Validity}

Disciriminant validity is a calculation of no indicator that gives loading to the latent variable whose value is higher than the latent variable it should be [16]. Discriminant validity can also be observed from the average variant extracted (AVE) for each indicator it is required to say the variable valid value (AVE)> 0.5 in order to be a good model. The following is the average variant extracted table.

Based on the AVE table above, it shows the variable purchase intention, perceived information seeking, perceived ease of use, trust, cost saving variable has a value of $>0.5$ which can be stated that each variable has valid discriminant validity.

Table 2. Discriminant Validity

\begin{tabular}{|l|c|c|c|}
\hline \multirow{2}{*}{ Variable } & \multicolumn{2}{|c|}{$\begin{array}{c}\text { Average Variant Ex- } \\
\text { tracted (AVE) }\end{array}$} & \multirow{2}{*}{ Verification } \\
\cline { 2 - 3 } & Men & Women & \\
\hline $\begin{array}{l}\text { Purchase In- } \\
\text { tention }\end{array}$ & 0.755 & 0.766 & Valid \\
\hline $\begin{array}{l}\text { Perceived In- } \\
\text { formation } \\
\text { Seeking }\end{array}$ & 0.623 & 0.523 & Valid \\
\hline $\begin{array}{l}\text { Perceived } \\
\text { Ease of Use }\end{array}$ & 0.683 & 0.569 & Valid \\
\hline Trust & 0.734 & 0.694 & Valid \\
\hline Cost Saving & 0.630 & 0.578 & Valid \\
\hline
\end{tabular}

\subsection{Composite Reliability}

Based on the convergent validity table above, it shows the variable purchase intention, perceived in-formation seeking, perceived ease of use, trust, cost saving variable has a value of $>0.5$ which can be stated that each variable has valid convergent validity.

Table 3. Composite Reliability

\begin{tabular}{|l|c|c|c|}
\hline \multicolumn{1}{|c|}{ Variable } & Men & Women & Verification \\
\hline Cost Saving & 0.872 & 0.844 & Reliable \\
\hline $\begin{array}{l}\text { Information } \\
\text { Seeking }\end{array}$ & 0.831 & 0.757 & Reliable \\
\hline $\begin{array}{l}\text { Perceived ease } \\
\text { of use }\end{array}$ & 0.865 & 0.796 & Reliable \\
\hline $\begin{array}{l}\text { Purchase inten- } \\
\text { tion }\end{array}$ & 0.902 & 0.907 & Reliable \\
\hline Trust & 0.892 & 0.871 & Reliable \\
\hline
\end{tabular}

\subsection{Path Coefficient}

Path coefficient evaluation is used to show how strong or the influence of exogenous variables, namely cost saving, information seeking, perceived ease of use and, trust for endogenous variables, namely purchase intention use. Then coefficient determination (R-square) is used to measure how strongly the endogenous variables are affected by other variables. There are several categories to see the value of the R-square [30]. The value of $0.19-0.33$ is in the weak category, then the value of 0.33 - 
0.67 is in the moderate category and for values $>0.67$ it is in a strong category. Based on the results of data processing that has been carried out from each variable the $\mathrm{R}$-square value is as follows:

Table 4. R-Square

\begin{tabular}{|c|c|c|c|c|}
\hline Variable & Men & $\begin{array}{c}\text { Cate- } \\
\text { gory }\end{array}$ & Women & $\begin{array}{c}\text { Cate- } \\
\text { gory }\end{array}$ \\
\hline $\begin{array}{c}\text { Purchase } \\
\text { Intention }\end{array}$ & 0.556 & $\begin{array}{c}\text { Moder- } \\
\text { ate }\end{array}$ & 0.459 & $\begin{array}{c}\text { Moder- } \\
\text { ate }\end{array}$ \\
\hline
\end{tabular}

Based on the table above, the R-square value of the purchase intention variable is 0.556 for men, that indicating that the exogenous and endogenous variable that affect endogenous variable are $55.6 \%$, which means that there are still $44.4 \%$ of the influence of other variables that can strengthen the purchase intention variable. Also $\mathrm{R}$-square value of the purchase intention variable is 0.459 for women, that indicating that the exogenous and endogenous variable that affect endogenous variable are $45.9 \%$, which means that there are still $54.1 \%$ of the influence of other variables that can strengthen the purchase intention variable.

\subsection{Hypothesis Testing}

Hypothesis testing in this study was carried out by looking at the value of T-statistics and the value of Pvalue, the research hypothesis can be declared accepted if the P-value is $<0.05$ or the value of T-statistics $>\mathrm{T}$ Table or 1.992 for men and T-statistics > T-Table or 1.988 for women. The following are the results of hypothesis testing obtained in this study through the inner model.

Hypothesis 1 connecting the exogenous cost-saving variable on purchase intention with gender moderation resulted that for men, the P-value was 0.001 , and the $\mathrm{T}$ statistic was 3.219> T-Table 1.992. And for women, the P-value was 0.000, and the T-Statistic was 3.965. > TTable 1988. From the results of the P-value which means both men and women consider the cost-saving variable to be one of the factors that influence consumers to make purchases using e-commerce. The higher the value of

Table 5. Hypothesis Testing

Table 5. Hypothesis Testing
\begin{tabular}{|c|c|c|c|c|c|c|c|c|}
\hline \multirow{2}{*}{ Hypothesis } & Path Coefficient & \multicolumn{2}{c|}{ T Statistic } & \multicolumn{2}{c|}{ P-Value } & \multicolumn{2}{c|}{ Decision } \\
\cline { 2 - 9 } & Men & Women & Men & Women & Men & Women & Men & Women \\
\hline H1 & 0.416 & 0.322 & 3.219 & 3.965 & 0.001 & 0.000 & Accepted & Accepted \\
\hline H2 & 0.303 & 0.223 & 2.640 & 2.462 & 0.009 & 0.014 & Accepted & Accepted \\
\hline H3 & 0.146 & 0.168 & 1.714 & 1.762 & 0.087 & 0.079 & Rejected & Rejected \\
\hline H4 & 0.150 & 0.205 & 1.676 & 2.212 & 0.094 & 0.028 & Rejected & Accepted \\
\hline
\end{tabular}

cost-saving, the more intentional to make purchases using e-commerce will increase. Hypothesis 1 was accepted by both men and women. Previous research stated that the cost-saving factor influences purchase intention, these are following the TAM theory, variable perceived usefulness has a positive impact on technology acceptance intention [23].

Hypothesis 2 connecting the exogenous trust variable to purchase intention with gender moderation resulted that for men, the P-value was 0.009 and the T-statistic was $2.640>\mathrm{T}$-Table 1.992, and the resulted for $2.462>1988$ T-Table. The results of the P-value mean that both men and women consider the trust variable as one of the factors that influence consumers to make purchases using e-commerce. The higher the value of trust from e-commerce, the intention to make purchases using e-commerce commerce will get increase. Hypothesis 2 was accepted by both men and women. Previous research said that the trust variable has a positive influence on purchase intention in e-commerce [16].

Hypothesis 3 connecting the exogenous perceived information-seeking variable on purchase intention with gender moderation resulted that for men the P-value was 0.087, and the T-statistic was $1.714<\mathrm{T}$-Table 1.992 . And the resulted for women, the P-value was 0.079, and the T-Statistic was 1,762<T-Table 1,988. From the results of the P-value which means that both men and women consider the perceived information-seeking variable is not a factor that influences consumers to make purchases using e-commerce. Hypothesis 3 was rejected by both men and women. Previous research that perceived information-seeking does not affect purchase intention in using e-commerce [31]

Hypothesis 4 connecting the exogenous variable perceived ease of use on purchase intention with gender moderation resulted that for men the P-value was 0.094 and the T-statistic was $1.676>$ T-Table 1.992 and resulted for women, the P-value was 0.028 and the T-Statistic of 2,212 > T-Table 1,988. From the results of the Pvalue which means that men consider the variable perceived ease of use is not a factor that influences consumers to make purchases using e-commerce. Hypothesis 4 women, the P-value was 0.014 , and the T-Statistic was 
was rejected for men. However, women consider the perceived ease of use variable to be one of the factors that influence women consumers to make purchases using ecommerce, or the higher the value of perceived ease of use from e-commerce, the intention to make purchases using e-commerce will get bigger. Hypothesis 4 was accepted for women. Previous research that perceived ease of use has a positive effect on purchase intention because perceived ease of use determines self-efficacy it has a positive impact on purchase intention in the open market [23].

\section{CONCLUSION}

From the results obtained, the factors that influence a person's intention to buy in e-commerce by using exogenous trust variables, perceived ease of use, perceived information seeking and, cost-saving by moderating gender variables during the covid-19 pandemic. The conclusion for men have 4-factors from an r-square of 0.556 or, there are still $44.4 \%$ variables that are not yet known with the variables accepted for men are variable trust and costsaving. Also, the results for female with these 4-factors from an r-square of 0.459 or, there are still $54.1 \%$ variables that are not yet known. The accepted variables for women are variable perceived ease of use, cost-saving, and trust. So from the results of the hypothesis that consumers have trust when shopping with e-commerce, and when shopping online, respondents believe that cost saving is better than shopping offline.

\section{REFERENCES}

[1] L. W. Okky, "Revolusi Industri 4.0 Tingkatkan PDB hingga USD150 Miliar, IniPenjelasannya," Okefinance, 2019. [Online]. Available: https://economy.oke-

zone.com/read/2019/04/22/320/2046291/revolusiindustri-4-0-tingkatkan-pdb-hingga-usd150-miliarini-penjelasannya?page $=1$. [Accessed: 03-Jul2021].

[2] R. Kelly, P. Brad, and C. Casey, Introduction to Information Systems Supporting and Transforming Business, 5th ed. Singapore: John Wiiley and Sons Singapore, 2015.

[3] L. C. Kenneth and T. G. Carol, E-commerce 2014 business. technology. societ, Tenth Edit. Pearson Education, 2014.

[4] D. D. Vivin, F. Aldo, and H. Erwin, "Pengguna Aktif Bulanan Aplikasi E-commerce di Indonesia dan Asia Tenggara," iprice, 2019. [Online]. Available: https://iprice.co.id/trend/insights/pengguna-aktifbulanan-aplikasi-e-commerce-di-indonesia-danasia-tenggara/. [Accessed: 03-Jul-2021].
[5] "McKinsey Expects Great Growth for Indonesia's E-Commerce Market," Indonesia Investments, 2018. [Online]. Available: https://www.indonesiainvestments.com/news/todays-headlines/mckinsey-expects-great-growth-for-indonesia-s-e-commerce-market/item8959? [Accessed: 03-Jul-2021].

[6] R. Leski, "Ekonomi Digital jadi Penopang Perekonomian di Tengah Pandemi," Kementrian Komunikasi dan Informasi, 2020. [Online]. Available: https://aptika.kominfo.go.id/2020/09/ekonomidigital-jadi-penopang-perekonomian-di-tengahpandemi/. [Accessed: 03-Jul-2021].

[7] T. Escobar-Rodríguez and R. Bonsón-Fernández, "Analysing online purchase intention in Spain: fashion e-ommerce,” Inf. Syst. E-bus. Manag., vol. 15, no. 3, pp. 599-622, 2017.

[8] F. Agmeka, R. N. Wathoni, and A. S. Santoso, "The influence of discount framing towards brand reputation and brand image on purchase intention and actual behaviour in e-commerce," Procedia Comput. Sci., vol. 161, pp. 851-858, 2019.

[9] L. Peng, W. Zhang, X. Wang, and S. Liang, "Moderating effects of time pressure on the relationship between perceived value and purchase intention in social E-commerce sales promotion: Considering the impact of product involvement," Inf. Manag., vol. 56, no. 2, pp. 317-328, 2019.

[10] Davis D Fred, "Perceived Usefulness, Perceived Ease of Use, and User Acceptance of Information Technology," MIS Q., vol. 13, no. 3, pp. 319-340, 1989.

[11] D. Straub, M. Limayem, and E. KarahannaEvaristo, "Measuring System Usage: Implications or IS Theory Testing," Manage. Sci., vol. 41, no. 8, pp. 1328-1342, 1995.

[12] D. R. Compeau and C. A. Higgins, "Computer SelfEfficacy: Measure And Initial Development Of A Test,” MIS Q., vol. 19, no. 2, pp. 189-211, 2017.

[13] J. C. F. Roig, J. S. García, and M. Á. M. Tena, "Perceived value and customer loyalty in financial services," Serv. Ind. J., vol. 29, no. 6, pp. 775-789, 2009.

[14] K. Miri and K. S. Sang, "Continuous Purchase Intention through Online Open Market Platform: Multidimensional Approach of Perceived Value in Purchasing Process and Transaction Satisfaction," J. Internet Electron. Commer. Resarch, vol. 19, no. 3, pp. 149-172, 2019.

[15] J. N. Sheth, B. I. Newman, and B. L. Gross, "Why We Buy What We Buy: A Theory of Consumption Values: Discovery Service for Air Force Institute of 
Technology,” J. Bus. Res., vol. 22, no. 2, pp. 159170, 1991.

[16] M. Dachyar and L. Banjarnahor, "Factors influencing purchase intention towards consumer-to-consumer e-commerce," Intang. Cap., vol. 13, no. 5, pp. 946-966, 2017.

[17] D. J. Kim, D. L. Ferrin, and H. R. Rao, "A trustbased consumer decision-making model in electronic commerce: The role of trust, perceived risk, and their antecedents," Decis. Support Syst., vol. 44, no. 2, pp. 544-564, 2008.

[18] N. Hajli, J. Sims, A. H. Zadeh, and M. O. Richard, "A social commerce investigation of the role of trust in a social networking site on purchase intentions," J. Bus. Res., vol. 71, pp. 133-141, 2017.

[19] J. S. Chiou, C. Droge, and S. Hanvanich, "Does Customer Knowledge Affect How Loyalty is Formed?, J. Serv. Res., vol. 5, no. 2, pp. 113-124, 2002.

[20] C. W. Choo, B. Detlor, and D. Turnbull, "Information seeking on the web: An integrated model of browsing and searching," First Monday, vol. 5, no. 2, 2000.

[21] F. D. Davis, R. P. Bagozzi, and P. R. Warshaw, "Extrinsic and Intrinsic Motivation to Use Computers in the Workplace," J. Appl. Soc. Psychol., vol. 22, no. 14, pp. 1111-1132, 1992.

[22] I. B. Hong and H. Cho, "The impact of consumer trust on attitudinal loyalty and purchase intentions in B2C e-marketplaces: Intermediary trust vs. seller trust," Int. J. Inf. Manage., vol. 31, no. 5, pp. 469479, 2011.

[23] S. S. Kim, "Purchase intention in the online open market: Do concerns for E-commerce really matter?," Sustainability, vol. 12, no. 3, 2020.

[24] V. Venkatesh, M. G. Morris, G. B. Davis, and F. D. Davis, "User Acceptance of Information Technology: Toward a Unified View," MIS Q., vol. 27, pp. 425-478, 2003.

[25] H. O. A. Wold, "oft Modeling: The Basic Design and Some Extensions," pp. 1-54, 1982.

[26] C. Fornell and C. J, Partial Least Square Advanced Methods in Marketing Research. Chicago: Oxford: Basil Blackwell Ltd, 1994.

[27] D. Barclay, C. Higgins, and R. Thompson, "The Partial Least Squares (PLS) Approach to Causal Modeling: Personal Computer Use as an Illustration," Technol. Stud., vol. 2, no. 2, pp. 285-309, 1995.

[28] C. Fornell, G. . Tellis, and G. . Zinkhan, "Validity Assessment: A Structural Equations Approach Using Partial Least Squares.," roceedings Am. Mark. Assoc. Educ. Conf., 1982.
[29] I. Ghozali and Hengky Latan, Partial Least Square Konsep, Teknik dan Aplikasi menggunakan Program SMARTPLS 3.0 untuk Penelitian Empiris, 2nd ed. Semarang: Universitas Diponegoro Semarang, 2012.

[30] J. Joseph F. Hair, G. T. M. Hult, C. M. Ringle, and M. Sarstedt, A primer on partial least squares structural equation modeling (PLS-SEM), Second. United States of America: Sage Publication, 2017.

[31] J. W. Putri, "Factors Affecting Customers Online Search Intention and Online Purchase Intention using Social Networks : Case Study of Online Shop on Instagram," iBuss Manag., vol. 3, no. 2, pp. 232240, 2015. 